\title{
Folliculogenesis/Oogenesis
}

\section{FOLLICULAR FLUID CONCENTRATION AND OOCYTE QUALITY FROM TOGGENBURG GOATS FED WITH UREA}

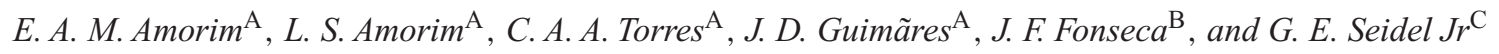 \\ A Federal University of Vicosa, Vicosa, Minas Gerais, Brazil; \\ ${ }^{B}$ Embrapa Goat Research Center, Sobral, Ceara, Brazil; \\ ${ }^{\mathrm{C}}$ Colorado State University, Fort Collins
}

\begin{abstract}
Protein and urea concentrations impair oocyte and embryo development in vivo and in vitro through an unclear mechanism. A possible way to understand this process is to determine the concentration of hormones and metabolites in follicular fluid associated with normal development. The objective of this study was to determine the effect of dietary urea levels on follicular fluid concentration of hormones and metabolites and oocyte quality. A trial was conducted with 9 nonpregnant and nonlactating Saanen goats, which had been distributed in a randomized design and fed with diets with $0(n=4)$ and $2.4 \%$ of urea in the total dry matter (DM) of the diet $(n=5)$. Before follicle aspiration by laparotomy, the goats were synchronized by inserting intravaginal sponges containing $60 \mathrm{mg}$ of acetate medroxyprogesterone (Progespon ${ }^{\circledR}$, Sintex) for 10 days followed by $125 \mu \mathrm{g}$ of cloprostenol (Ciosin ${ }^{\circledR}$ Coopers) $48 \mathrm{~h}$ before the removal of the sponge. The sponge was removed immediately before the follicular aspiration. The follicular development was stimulated with $70 \mathrm{mg}$ of NIH-FSH-P1 (Folltropin $\mathrm{V}^{\circledR}$ Vetrepharm) i.m., and $300 \mathrm{IU}$ of eCG i.m., (Novormon ${ }^{\circledR}$ Sintex) given $36 \mathrm{~h}$ before the follicular aspiration. Fluid from the 2 lartest follicles of each ovary were analyzed to determine the concentration of estradiol, progesterone, and testosterone by quimioluminesence, and glucose and urea concentrations were measured by enzymatic kit. The other follicles in each ovary were aspired with new needles and syringes and the oocyte quality was recorded. Oocytes were classified according to cytoplasma aspect and number of granulosa cells: Class A (dark cytoplasm and uniform aspect) with 3 (AMG) and $<3$ layers of cumulus cells (AmG); class B (cytoplasm with color alterations, desuniform aspect and vacuoles) with 3 (BMG) and $<3$ layers of cumulus cells $(\mathrm{BmG})$; number of partially denuded oocytes (PD) and number of denuded oocytes (DO). Data were analyzed by ANOVA and treatment difference separated by SNK test. Follicular fluid estradiol concentration was lower in goats fed with urea $\left(4.02 \pm 0.16 ; 4.97 \pm 0.18 \mathrm{ng} \mathrm{mL}^{-1} ; P<0.05\right)$, progesterone concentration did not differ between treatments $(2.48 \pm 0.58 ; 3.37 \pm 0.52 \mathrm{ng} \mathrm{mL}-1 ; P>0.05)$, testosterone concentration was lower in the control animals $\left(1.17 \pm 0.48 ; 3.20 \pm 0.43 \mathrm{ng} \mathrm{mL}^{-1} ; P<0.05\right)$. The glucose $\left(91.44 \pm 3.60 ; 84.78 \pm 5.58 \mathrm{mg} \mathrm{dL}^{-1}\right)$ and urea concentration $(23.04 \pm 1.06 ; 18.00 \pm 2.35)$ were greater in the animals treated with $2.4 \%$ compared with $0 \%$ of urea $(P<0.05)$, respectively. The number of oocytes in the different categories was not affected by treatment $(P>0.05)$ : AMG $1.20 \pm 1.09 v .0 .50 \pm 0.57$, AmG 4.20 $\pm 2.16 v .3 .50 \pm 3.10, \mathrm{BMG}$ $0.40 \pm 0.54 v .0 .25 \pm 0.50$, BmG $1.40 \pm 0.54 v .1 .75 \pm 1.25$, DO $10.20 \pm 3.76 v .11 .50 \pm 5.44$, in the 0 and $2.4 \%$ of urea groups respectively. Only the number of $\mathrm{PD}(1.60 \pm 0.54 v .3 .50 \pm 1.91)$ recovered from animals treated with $2.4 \%$ was greater than in controls $(P<0.05)$. The hormone and metabolites concentration in follicular fluid as well as the oocyte quality was affected by the urea concentration of the diet.
\end{abstract}

Supported by grant from: CNPq, FAPEMIG, Shering Plough ${ }^{\circledR}$, Tecnopec $^{\circledR}$, Carbogel $^{\circledR}$.

\section{ADMINISTRATION OF GnRH ON DAY 6 ALTERS THE NUMBER OF FOLLICULAR WAVES FROM 2 TO 3 DURING THE ESTROUS CYCLE OF HOLSTEIN COWS}

\author{
E. Dirandeh, H. Kohram, and A. Zare Shahneh
}

Department of Animal Science, Faculty College of Agriculture and Natural Resources, The University of Tehran, Karaj, Tehran, Iran

It is suggested that pregnancy rate is greater in lactating cows inseminated following ovulation of a third-wave follicle compared with a second-wave follicle. The number of follicular waves is not apparent during the estrous cycle. However, GnRH injection on Day 6 is supposed to initiate a new follicular wave earlier; as a result, the number of cows with 3 follicular waves will be increased. This study was done to change the 2 -follicular-wave cycles to 3 follicular waves during the estrous cycle. The estrous cycles of 10 cows were synchronized with 2 i.m. injections of prostaglandin $\mathrm{F}_{2 \alpha}$ given 11 days apart. The cows were randomly assigned to 1 of 2 treatments. Cows in the control treatment received no treatment, whereas GnRH6 